\title{
Aloe vera and STS solution on microbial population and vase life of Heliconia cut flowers
}

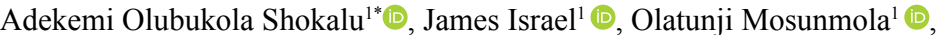

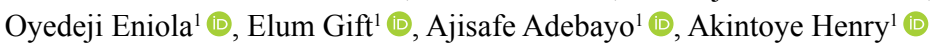

${ }^{1}$ National Horticultural Research Institute (NIHORT), Jericho Reservation Area, Idi-Ishin, Ibadan-Oyo State, Nigeria

\begin{abstract}
The use of several solutions as floral preservatives in extending the vase life of cut flowers has been an all-time research objective to meet the demands of florists and buyers. One of the major problems faced with the longevity of cut flowers is the accumulation of microorganism in the vase floral solution. This study was carried out to investigate the influence of Aloe vera gel and Silver thiosulphate solutions used as vase solution on the microbial population of Heliconia cut flowers. The experiment was carried out in the plant physiology laboratory, Floriculture programme, National Horticultural Research Institute, (NIHORT); Ibadan, Nigeria $(7 \mathrm{O} 25$ " N and $3 \mathrm{O} 52$ " E). Six treatments supplemented with $1 \%$ sucrose were used in this experiment, they include; $1 \%, 2 \%$ and $4 \%$ Aloe vera gel solutions, $0.5 \%$ and $1 \%$ Silver thiosulphate solutions and distilled water (which serve as control) labeled AV1, AV2, AV3, STS1, STS2 and CO respectively. All treatments used for the vase life of Heliconia cut flowers were significantly ( $p \leq$ 0.05 ) different in the parameters analyzed as compared to the control. The vase life, relative fresh weight and relative water content of Heliconia cut flowers were best with Aloe vera gel solutions compared to the control with AV3 recording the longest vase life of 12 days $(58.21 \%)$. The microbial population in the vases of the cut flowers was greatly reduced with the application of the silver thiosulphate solutions (STS1 and STS2) compared with the control with STS2 recording the lowest microbial colony at 32.67 CFU $\mathrm{mL}-1$. Promoting the use of organic floral preservatives should be encouraged as it is eco-friendly and cost effective. The result of the study reveals that the use of $4 \%$ Aloe vera solution has the potential to reduce microbial growth and also enhance the longevity of the cut flowers.
\end{abstract}

Keywords: Aloe vera, longevity, microorganism, post-harvest, silver thiosulphate.

\section{Resumo}

Aloe vera e STS na população microbial e vida de vaso de Heliconia de corte

O uso de diversas soluções conservantes na extensão da vida de vaso de flores de corte é um tema de pesquisa importante e visa a atender a demanda mercadológica de floristas e consumidores. Um dos maiores problemas relacionados à longevidade de flores de corte é o acúmulo de microraganismos na solução de vaso. Este estudo foi conduzido para investigar a influência do gel de Aloe vera e do tiossulfato de prata como aditivos de solução conservante para o controle da população microbial em Heliconia de corte. O experimento foi conduzido no Laboratório de Fisiologia, programa de floricultura, National Horticultural Research Institute, (NIHORT); Ibadan, Nigeria ( $7^{\circ} 25^{\prime}$ N e $3^{\circ} 52^{\prime}$ E). Foram delineados seis tratamentos contendo $1 \%$ sucrose além de $1 \%, 2 \%$ and $4 \%$ Aloe vera gel ou $0,5 \%$ e $1 \%$ de tiossulfato de prata ou água destilada (tratamento controle), denotados por AV1, AV2, AV3, STS1, $\mathrm{STS}_{2}$ and CO respectivamente. Todos os tratamentos empregados para o aumento da vida de vaso de Heliconia de corte foram estatisticamente $(p \leq 0,05)$ diferentes nos parâmetros analisados quando comparados com o tratamento CO. A vida de vaso, peso fresco relative, e conteúdo relative de água de Heliconia de corte tiveram melhor desempenho com as soluções contendo gel de Aloe vera quando comparadas com o controle, enquanto o tratamento $\mathrm{AV}_{3}$ registrando a maior vida de vaso com 12 days $(58,21 \%)$. A população microbial nos vasos das flores de cored foram drasticamente reduzidas com a aplicação de tiossulfato de prata (STS1 and STS2) na solução conservante quando comparado com o controle, e o tratamento STS registrou a menor contagem de colônias com 32,67 CFU mL $\mathrm{mL}^{-1}$. A promoção de preservativos florais orgânicos deveria ser ampliadas pois mostrou-se efetiva com uso de gel de Aloe vera, além de ser ambientalmente amigável e apresentar bom custo-benefício. O resultado deste estudo revelou que o uso de gel de Aloe vera a 4\% tem o potencial de reduzir o crescimento microbiano e aumentar a longevidade de flores de corte.

Palavras-chave: Aloe vera, longevidade, microrganismos, pós-colheita, tiossulfato de prata.

https://doi.org/10.1590/2447-536X.v27i4.2356

* Corresponding author: kemishokalu@yahoo.co.uk

Received: Feb 15, 2021 | Accepted: July 6, 2021 | Available online: Aug 9, 2021

Licensed by CC BY 4.0 (https://creativecommons.org/licenses/by/4.0/)

Area Editor: Bruno Trevenzoli Favero 


\section{Introduction}

In Nigeria, the cut flower business has been one of the major sectors in floriculture and it is gradually experiencing an increase in profitability especially in the Southern and Central parts of the country. According to the National Bureau of Statistics (NBS), from April 2019 to March 2020, the cut flowers and flower buds generated 1.96 billion naira within the period (NBS, 2020). To date, the major challenge faced with cut flower production and distribution has been the longevity of the cut flowers. Heliconia (Golden torch) is one of the beautiful and popular cut flowers in Nigeria. Many species of the plant are found in the tropics (Albuquerque et al., 2014, Omovbude et al., 2016). In addition to their exotic beauty, they also have a natural postharvest vase life of 6-8 days after which senescence occurs resulting in rapid wilting of the petals. Often times, the shortened vase life of cut flowers are due to some physiological and biochemical factor such as induced stress on the cut stems, microbial contamination, air embolism and nutrient deficiency (Jagreeti and Dubey, 2018). Most studies have focused on hormone application to prolong cut flowers longevity, however, it is pertinent to consider other important aspect of cut flower postharvest treatment such as impeding microbial contamination of vase solutions (Jowkar, 2015). The presence and accumulation of microorganisms in vases of cut flowers contributes significantly to wilting. This is because they cause vascular blockage and occlusion of water flow in the stem. Babarabie et al., 2015 reported that in order to increase the vase life of cut flowers, various combinations are usually used. Sucrose in preservative solutions improves the quality and longevity after the harvest, but it also increases the microorganisms' growth, so along with the use of sugar, antimicrobials should be used in the preservative solutions of cut flowers. Floral preservatives have been found to delay senescence by suppressing microbial growth and promoting solution uptake due to reduction in vascular blockades (Balieiro et al., 2018). The use of ethylene antagonist such as silver thiosulfate solution (STS) and organic preservative (Aloe vera gel solution) has been shown to mitigate postharvest cut flower losses (Dar and Tahir, 2018). Aloe vera is widely known for its high medicinal values, as it possesses high antimicrobial, antifungal and preservative properties (Hes et al., 2019) such as the anthraquinones; Aloin and Emodin. Therefore, this study is aimed at evaluating the vase life and physiological performance of Heliconia (Golden torch) cut flowers with the use of Aloe vera and STS solutions as floral preservatives and their effect on microbial population during postharvest handling.

\section{Materials and Methods}

\section{Plant materials}

Flowering stems of Heliconia spp. with three to five open bracts were harvested early in the morning from the floriculture garden, NIHORT. The leaves on the lower section of the stems were removed and the stems were cleaned and recut at an angle under water so that all flowers reach a height of $30 \pm 0.5 \mathrm{~cm}$ before treatment in order to remove probable air emboli and kept in water for about 5 minutes until the commencement of the experiment.

\section{Experimental design and treatments}

The experiment was laid out in a Completely Randomized Design (CRD) of six treatments with four replicates. The treatments (floral preservatives) used in this experiment includes $1 \%, 2 \%$ and $4 \%$ of Aloe vera solutions (the gel extract was obtained from freshly harvested Aloe vera plants from the floriculture garden); $0.5 \%$ and $1 \%$ of $0.02 \mathrm{M}$ silver thiosulphate solution (which was prepared by slowly pouring $20 \mathrm{~mL}$ of $0.1 \mathrm{M}$ silver nitrate stock solution into $80 \mathrm{~mL} 0.1 \mathrm{M}$ sodium thiosulphate stock solution); while distilled water was used as control. The treatments were supplemented with $1 \%$ sucrose and each had four 100 $\mathrm{mL}$ transparent plastic vases containing $50 \mathrm{~mL}$ of floral solution with cut flowers.

The stems were cut to uniformity and placed in the already prepared floral preservative solution. Vase solutions were not changed throughout the experiment.

\section{Experimental condition}

The experiment was carried out at the Floriculture Laboratory of the National Horticultural Research Institute (NIHORT) Ibadan, Nigeria (7025" N and 3052" E). Cut flowers of Heliconia were kept in a postharvest laboratory with a relative humidity $(\mathrm{RH})$ of $70 \% \pm 5 \%$, maximum and minimum temperature of $25 \pm 2^{\circ} \mathrm{C}$ and $22 \pm 2^{\circ} \mathrm{C}$, respectively. Light was provided by sunshine with an intensity of 140 $\mu \mathrm{mol} \mathrm{m} \mathrm{m}^{-2} \mathrm{~s}^{-1}$ and a light/dark cycle of 13/11 hours. Flowers were checked daily and their appearance was recorded. The laboratory was well ventilated with open windows.

\section{Vase life}

Vase life was determined as the time period for which a spike of cut flower retained $50 \%$ freshness. Vase life termination was considered when bent neck was observed or five outer petals were wilted.

\section{Microbial Population}

Microbial population was determined by Plate Count Method. To determine the microbial population in the vase, $1 \mathrm{~mL}$ aliquot solution was taken from each vase solution containing cut flowers on the $12^{\text {th }}$ day after commencement of the experiment. The samples were serially diluted up to 10 -fold and $1 \mathrm{~mL}$ of each dilution was cultured on a solidified nutrient agar medium with 3 replications. Sample plates were incubated at $28 \pm 2{ }^{\circ} \mathrm{C}$ for 48 -hours to allow microorganisms growth. Bacterial colony units formed after incubation were counted. Colony counts were expressed as colony forming units per $\mathrm{mL}\left(\mathrm{CFU} \mathrm{mL} \mathrm{mL}^{-1}\right)$.

\section{Data Analysis}

The postharvest physiology parameters collected (fresh weight change, petals changes and microbial population counts) were studied and statistically analyzed using SAS 9.0 software. Each value represents the mean of four 
independent replicates. The significance of the difference among treated means was computed using least significance difference (LSD) test at 5\% level of significance. Microbial data were subjected to analysis of variance (ANOVA) and means were separated using Duncan Multiple Range Test (DMRT) at 0.05 of probability level.

\section{Result and Discussion}

Decrease in weight change plays a vital role in the turgidity and longevity of cut flowers. The results of the relative fresh weight of Heliconia cut flowers (Figure 1) show that there was no significant difference in the Aloe vera solution treatments up to day 6 , however, there was a significant $(p \leq 0.05)$ difference in the Aloe vera treatments from day 9 . By day $12,4 \%$ Aloe vera gel solution recorded the highest value of $69.53 \%$. Treatment with STS solution showed no significant difference up to day 9. By day 12, there was a significance $(p \leq 0.05)$ difference in the STS treatment. $1 \%$ STS had a higher value of $59.87 \%$ compared to $0.5 \%$ STS and the control.

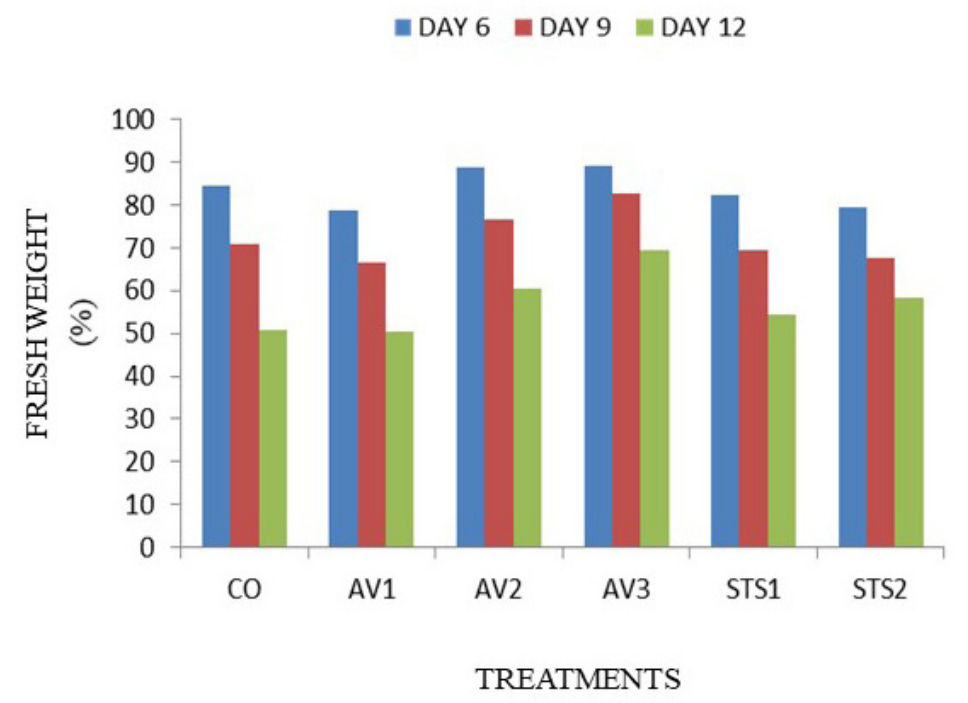

Figure 1. Effect of aloe vera and STS on the relative fresh weight of Heliconia cut flowers. $(\mathrm{CO}=\mathrm{Control}, \mathrm{AV} 1=1 \%$ Aloe vera gel solution, $\mathrm{AV} 2=2 \%$ Aloe vera gel solution, $\mathrm{AV} 3=4 \%$ Aloe vera gel solution, STS1 $=0.5 \%$ Silver Thiosulphate solution, STS2 $=1 \%$ Silver Thiosulphate solution)

Both Aloe vera gel solutions and STS solutions were significantly higher than the control. The lowest value recorded on the fresh weight of the cut flowers by day 12 was with the control $(50.60 \%)$. This study is in accordance with Selamawit et al. (2018) that report that termination of cut flowers vase life can be caused by water imbalance within the vascular cells thereby resulting in wilting.
Beside the relative fresh weight, the relative water content is an also index indicating the water holding capacity of the plant organs and shows the ability of the plant to withstand water stress conditions (Farinas et al., 2019). Figure 2 shows that there was a significant ( $p \leq$ $0.05)$ difference in the cut flowers in relation to water content. 


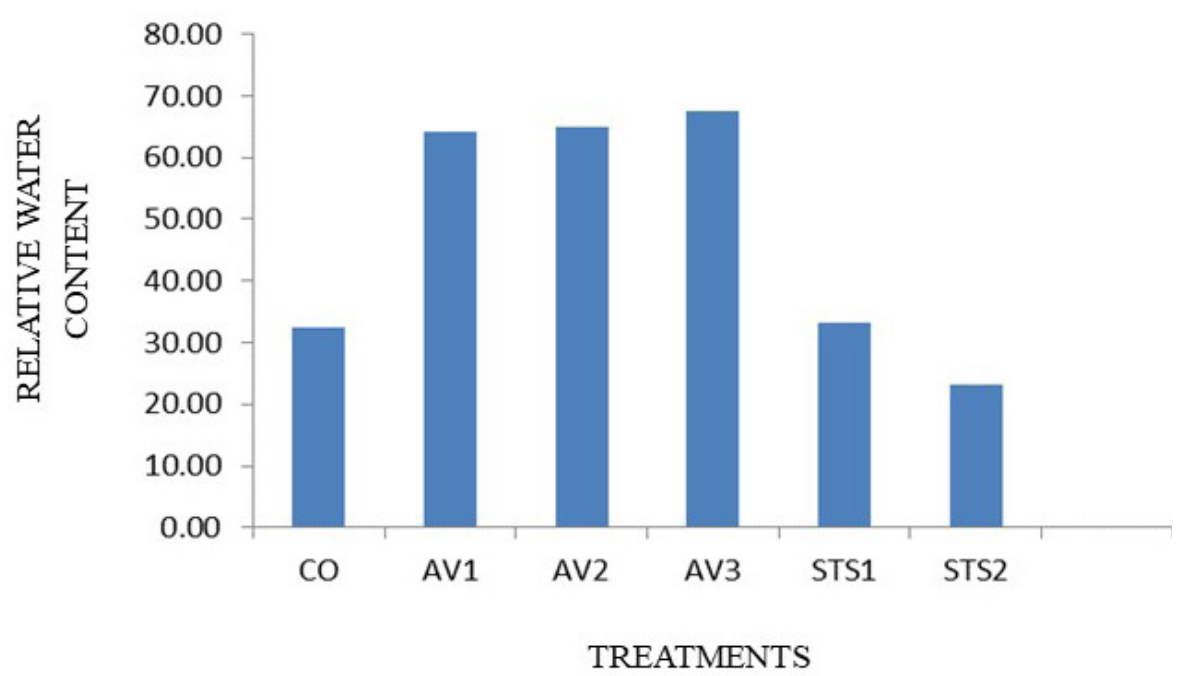

Figure 2. Effect of aloe vera and STS on the relative water content of Heliconia cut flowers. $(\mathrm{CO}=\mathrm{Control}, \mathrm{AV} 1=1 \%$ Aloe vera gel solution, $\mathrm{AV} 2=2 \%$ Aloe vera gel solution, $\mathrm{AV} 3=4 \%$ Aloe vera gel solution, STS1 $=0.5 \%$ Silver Thiosulphate solution, STS2 $=1 \%$ Silver Thiosulphate solution)

The treatment with Aloe vera gel solutions was not significantly different from each other. However, there was a significantly $(p \leq 0.05)$ different compared to STS treatments and control. The highest relative water content value recorded was 77.49 by $4 \%$ Aloe vera while the lowest value was recorded by $1 \%$ STS (23.14). Chrysargyris et al. (2016) reported that Aloe vera gel solution can be used to increase and maintain the relative water content in plants.

There was a significant $(p \leq 0.05)$ difference in the microbial population in the vase life of Heliconia cut flowers with the application of floral treatments. Results in Table 1 shows that STS and $_{1}$ STS $_{2}$ solutions significantly reduced the bacterial population in the vase.

Table 1. Effect of aloe vera and STS on the bacterial population in the floral solutions

\begin{tabular}{|c|c|}
\hline Treatment & Bacteria population $(\mathbf{C F U} / \mathbf{m L})$ \\
\hline $\mathrm{STS}_{1}$ & $45.00^{\mathrm{c}}$ \\
\hline $\mathrm{STS}_{2}$ & $32.67^{\mathrm{d}}$ \\
\hline $\mathrm{AV}_{1}$ & $63.33^{\mathrm{b}}$ \\
\hline $\mathrm{AV}_{2}$ & $67.33^{\mathrm{b}}$ \\
\hline $\mathrm{AV}_{3}$ & $68.67^{\mathrm{b}}$ \\
\hline $\mathrm{CO}$ & $408.00^{\mathrm{a}}$ \\
\hline
\end{tabular}

Values are obtained from the mean of 4 replications. Means with the same alphabet in the same column are not significantly different $(p \leq 0.05)$ Duncan's multiple range test.

$(\mathrm{CO}=\mathrm{Control}, \mathrm{AV} 1=1 \%$ Aloe vera gel solution, $\mathrm{AV} 2=2 \%$ Aloe vera gel solution, $\mathrm{AV} 3=4 \%$ Aloe vera gel solution, $\mathrm{STS} 1=0.5 \%$ Silver Thiosulphate solution, STS2 $=1 \%$ Silver Thiosulphate solution)

Inhibitory effect of STS1 and STS2 solutions on bacterial growth may be due to presence of antimicrobial properties of silver thiosulphate. Bacterial population in the vase treated with Aloe vera (AV1, AV2 and AV3) was not significantly different among each other but significantly ( $p$ $\leq 0.05$ ) lower compared with the control. A higher microbial population was recorded in the control. Effectiveness of Aloe vera gel solution in reducing bacterial population in this study may be due to presence of secondary metabolites in the plant that inhibit the microbial growth (Oghenemaro et al., 2018; Danish et al., 2020). Aloe vera exudate contains the secondary metabolite called 'aloes' or 'bitter aloes' which is present in the pericycle cells of the vascular bundles in the leaf. This may likely be responsible for the slight alkalinity of the solutions and for the decrease in microbial growth. This result also corroborates the findings 
of Solgi (2018) who reported that antimicrobial compounds reduced bacterial colonies and extended the vase life of carnation cut flowers.

The vase life of cut flowers is the most important parameter when considering the longevity of cut flowers. Shahram et al. (2020) reported that the use of ethylene antagonist Silver Thiosulfate Solution (STS) and other floral preservative has been shown to reduce the postharvest losses of cut flowers. And this corresponds with our results as STS and Aloe vera gel floral preservatives were able to extend the vase life of Heliconia cut flowers beyond 9 days. The highest vase life recorded was with $4 \%$ Aloe vera gel solution which extended the vase life of Heliconia cut flowers beyond 12 days (Figure 3).

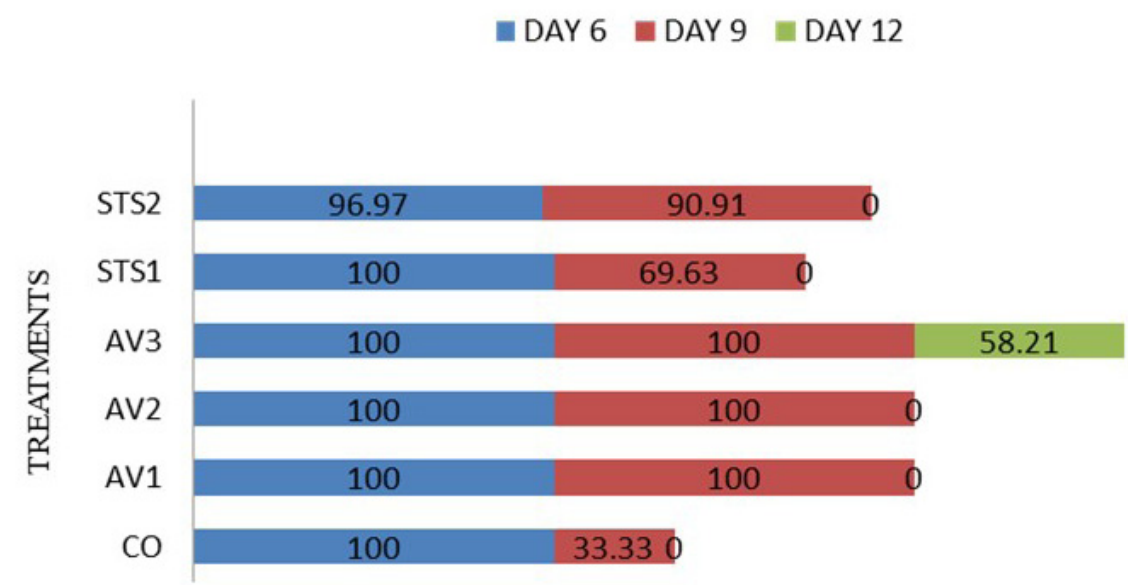

Figure 3. Effect of aloe vera and STS on the vase life of Heliconia cut flowers

$(\mathrm{CO}=\mathrm{Control}, \mathrm{AV} 1=1 \%$ Aloe vera gel solution, $\mathrm{AV} 2=2 \%$ Aloe vera gel solution, $\mathrm{AV} 3=4 \%$ Aloe vera gel solution, STS $1=0.5 \%$ Silver Thiosulphate solution, STS $2=1 \%$ Silver Thiosulphate solution)

Sudaria et al. (2017), also reported that Aloe vera gel solution used as floral treatment has the potential of increasing the longevity of cut flowers.

\section{Conclusions}

Reducing the population of microorganisms in holding solutions of cut flowers can significantly improve the longevity of cut flowers. Aloe vera have antimicrobial properties that help in reduced microbial growth. STS is an ethylene antagonist that slows down senescence in cut flowers. This study has showed that Aloe vera and STS floral preservative solution were effective in impeding the growth of microorganisms and also increasing the longevity of the Heliconia cut flowers.

\section{Author Contribution}

SA: conceptualization, investigation, methodology, supervision, writing - review and editing, validation. JI: conceptualization, investigation, methodology, data curation, analysis, writing - original draft, writing - review and editing. OM: conceptualization, investigation, analysis. OE: data curation, microbial analysis, investigation, writing - original draft, writing - review and editing. EG: data curation, microbial analysis, evaluation, writing - review and editing. AA: supervision, validation. AH: supervision, validation.

\section{Acknowledgements}

The authors gratefully acknowledge support and funding under Project 8 of the National Horticultural Research Institute (NIHORT), Idi-Ishin, Ibadan, Nigeria. Assistance from Mrs. Oluwatoyin Ojo, Mr Yekini Tunde and Michael Adeleke are also acknowledged.

\section{References}

ALBUQUERQUE, A.W.; SANTOS, J.M.; FARIAS, A.P. Produtividade e qualidade pós-colheita de helicônia Golden Torch submetida a fonte e doses de silício. Revista Brasileira de Engenharia Agrícola e Ambiental, v.18, p.173-179, 2014.

BABARABIE, M., ZAREI, H., VARASTEH, F. The effect of rosemary essential oils and thymol on vase life and some physiological characteristics of Alstroemeria cut flowers. International Journal of Agriculture and Biosciences, v.4, n.3, 122-126, 2015.

CHRYSARGYRIS, A., NIKOU, A., TZORTZAKIS, N. Effectiveness of Aloe vera gel coating for maintaining tomato fruit quality. New Zealand Journal of Crop and Horticultural Science, v.44, n.3, p. 203-217, 2016. https:// doi.org/10.1080/01140671.2016.1181661 
DANISH, P.; ALI, Q.; HAFEEZ. M.; MALIK, A. Antifungal and antimicrobial activity of aloe vera plant extract. Biological and Clinical Science Research Journal, v.2020, e004, 2020.

DAR, R.; TAHIR, I.; Effect of ethylene antagonist silver thiosulphate on the flower longevity of Clarkia pulchella pursh. Journal of Horticultural Research, v.26, n.1, p.512, 2018.

FARIÑAS, M.D.; JIMENEZ-CARRETERO, D.; SANCHO-KNAPIK, D.; PEGUERO-PINA, J.; GILPELEGRIN, F.; ALVAREZ-ARENAS, T. Instantaneous and non-destructive relative water content estimation from deep learning applied to resonant ultrasonic spectra of plant leaves. Plant Methods, v.15, 128, 2019. https://doi. org/10.1186/s13007-019-0511-z

HEŚS M, DZIEDZIC K, GÓRECKA D, JĘDRUSEKGOLIŃSKA A, GUJSKA F. Aloe vera (L.) Webb: Natural Sources of Antioxidants - A Review: Plant Foods for Human Nutrition, v.74, n.3, p.255-265, 2019. https://doi. org/10.1007/s11130-019-00747-5

JAGREETI G.; DUBEY, R.K. Factors affecting post-harvest life of flower crops. International Journal of Current Microbiology and Applied Sciences, v.7, n.1, p.548-557, 2018. https://doi.org/10.20546/ijcmas.2018.701.065

JOWKAR, M.M. Effects of chlorination and acidification on postharvest physiological properties of alstroemeria, cv. 'Vanilla' and on microbial contamination of vase solution. Horticulture, Environment, and Biotechnology, v.56, p.478-486, 2015. https://doi.org/10.1007/s13580015-0022-4

OGHENEMARO, E.F.; JOHNSON, J.; ITOHAN, I.M.; RICHARD, S.O.; MICHAEL, O. Antimicrobial activity of Aloe vera gel and honey against bacteria isolates from wound aspirates. International Journal of Pharmaceutical Science \& Research, v.9, n.11, p.4890-4893, 2018. https:// doi.org/10.13040/IJPSR.0975-8232.9(11).4890-93.
OMOVBUDE, S.; ONI, O.O.; AZAGBA, E. Growth responses of two varieties of Heliconia flowers to selected growth media in Port Harcourt, South-South Nigeria. African Journal of Plant Science, v.10, n.3, p.68-76, 2016.

SAS Computer program. SAS/STAT User's Guide: Statistical Methods, 6ed. Iowa, Iowa State University Press, 1994.

SELAMAWIT, Z.; MELKAMU, A.; TADELE, Y. Pulsing preservatives to prolong vase life of cut rose flowers in Bahir Dar, Northwestern Ethiopia. International Journal of Sustainable Agricultural Research, v.5, n.4, p.54-67, 2018.

SEDAGHATHOOR, S.; NAROUEI, Z.; SAJJADI, S.A.; SAEED, P.; LLORENS, E. The effect of chemical treatment (silver thiosulfate and putrescine) on vase life and quality of cut Chrysanthemum morifolium (Ram.) flowers. Cogent Biology, v.6, n.1, 2020. https://doi.org/10.1080/23312025. 2020.1754320 .

SOLGI, M. The application of new environmentally friendly compounds on postharvest characteristics of cut carnation (Dianthus caryophyllus L.). Brazilian Journal of Botany, v.41, p.515-522, 2018. https://doi.org/10.1007/ s40415-018-0464-X

SUDARIA, M.A.M.; UTHAIRATANAKIJ, A.; NGUYEN, H.T. Postharvest quality effects of different vase life solutions on cut rose (Rosa hybrida L.) International Journal of Agriculture, Forestry and Life Science, v.1, n.1, p.12-20, 2017. 